\title{
Houses, ideas and resisting the natural
}

\section{Pete Bossley}

As an introductory gesture, I offer the following very personal response to some key elements of On Adams House in Paradise/Pacific. "Adam", for instance, comes hand-in-hand with Christian sin, falling, a web of guilt. For me, these have no personal relevance. "House": an interesting idea, worthy of lifelong architectural study. "Paradise": the notion of an abode of righteous souls after death is (or should be) of waning significance. The Persian metaphor of a walled garden of delights seems more architecturally fertile. "Pacific": peace(ful). Many would consider the action of humans upon this island to be aggressive and not in the least peaceful.

A superficial response? Yes. Of course Adam's position in European mythology is hugely important, but the central notion implicit in the title Adam's House in the Pacific is the idyllic primitive hut in untended, yet benign, vegetation. Man at peace with a benevolent nature: a nostalgic fantasy. For my part, placing a house in the landscape has nothing whatsoever to do with origins (first man), singularity (man alone), origins (primal house form) or paradise (benign nature). It has more resonance with Persian notions of paradise: a garden, created by humans, walled to keep chaos at bay.

The New Zealand landscape is, largely, a human project of burning off, clearing and eviscerating, controlling and domesticating the land. The forest (which we enervate by calling it bush) is far from benign: it is chaotic, aggressive, uninhabitable. We have corralled it into zones and driven roads, tracks and paths through it which let us venture into it - without venturing into it.

We have modified the country radically. We have designed it. Where forest was, there are now fields, paddocks, roads, windbreak treelines, dammed lakes, skifields, racecourses, farmhouses, towns. Heavily fertilised fields, horrendously polluted lakes. But we persist in calling it natural. As a nation, whether or not we believe in it, we seem to glean pleasure from believing in our phenomenally successful international PR hype: Clean Green and 100\% Pure.

References to Adam, to the idyllic, and to 'man alone' myths deny our role in the reworking of the country. So, too, does our obsession with the 'bach', which gets increasingly sad as the cultural and social conditions which spawned it fade into history. Instead, we should accept that we started redesigning the country the moment we set foot on it. We need to acknowledge and celebrate this fact and, as designers, accept responsibility and do our job well.

The houses we insert into this man-scape are no primitive huts, nor do they purport to be. Nor do the clients believe that they are returning to Nature. When they 
The depth of geological forces contrasts with the taut qualities of the realm of human habitation. The site of the Emirali House (1986) in West Harbour had been cleared of all vegetation, leaving a bare, rolling clay surface: exposed, vulnerable, mobile land. The impact of slippage and heaving, of expansion and contraction, were evident. This unsettled condition was incorporated into the design. Five discrete elements offer interpretations of disruptions of a previous mode of balance, or of the process of finding that mode.
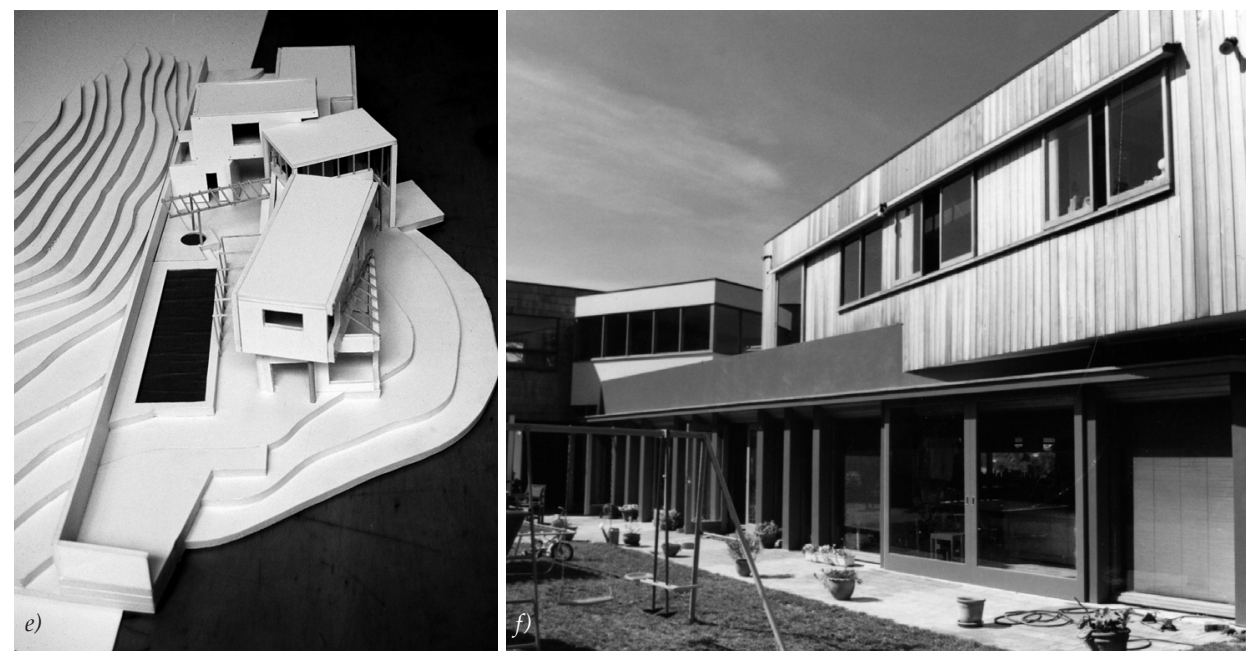

The insubstantiality of vegetation, as a skin draped over and covering the flesh underneath, is often illuminated by the cuts made for road works. The experience of passing through vertiginous walls of clay, as well as over the undulating surface, was central to the design of the $\mathrm{Z}$ House. The two-storey building, on rolling countryside near Hamilton, is partially buried. When approached along the rural driveway, it appears as single storey. A Z-shaped masonry retaining wall, cutting into the ridge, leads into the east-facing arrival court, where the experience of being under the surface begins. In the sub-surface spaces, awareness is focused on the sky overhead, as though lying on one's back looking up. The $\mathrm{Z}$ curves through the house eventually to define a west-facing courtyard. Where the ridge drops away towards the west, courtyard and house resurface and become two visible storeys again.
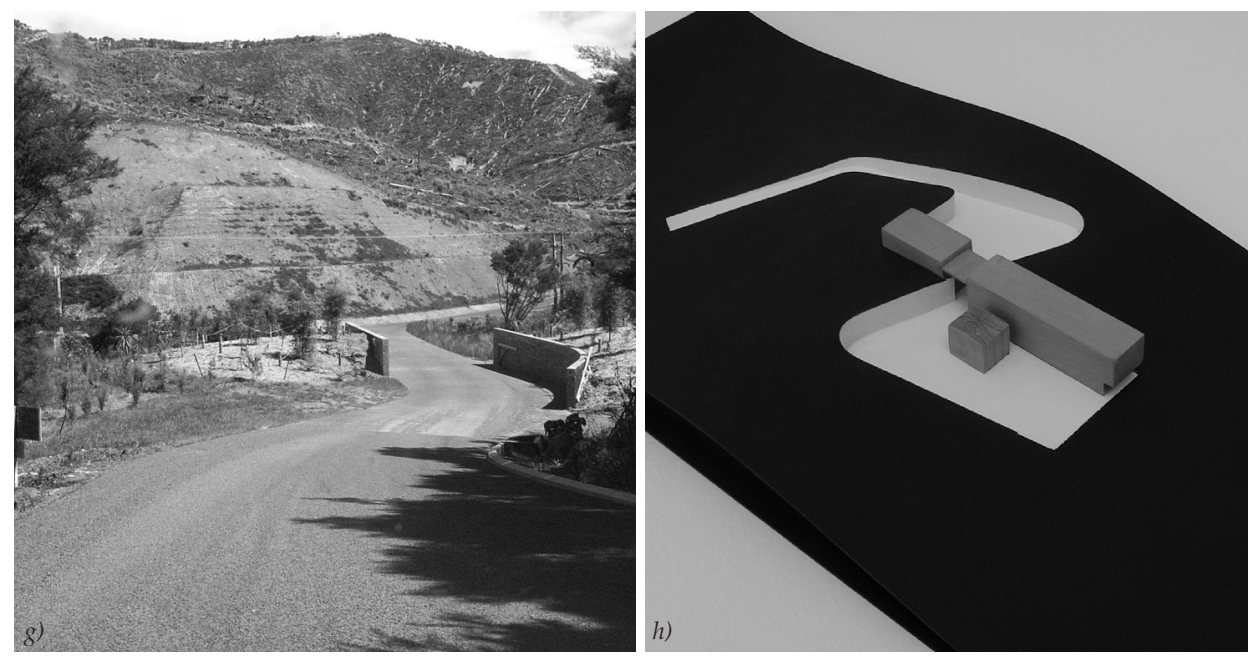

e) Emirali House, West Harbour (1986), model. Photo: Pete Bossley Architects f) Emirali House. The unsettled composition is highlighted by the different materials ascribed to each block. Photo: Pete Bossley Architects g) Roadside cuts expose the 'flesh' of the land. Photo: Pete Bossley Architects. h) Z House (Hamilton, 2001), model. Photo: Pete Bossley Architects 
Z House. The curving cut in the land passes through house from south to north. Photo: Simon Devitt.

a) Paroa 2 House (Bay of Islands,2003), from southeast. The partially underground sleep-outs gather around the lawn and the large terrace of the living wing. Photo: Pete Bossley Architects.

b) Varying degrees of closure in PBA designed 'encampments'. Photo: Pete Bossley Architects.

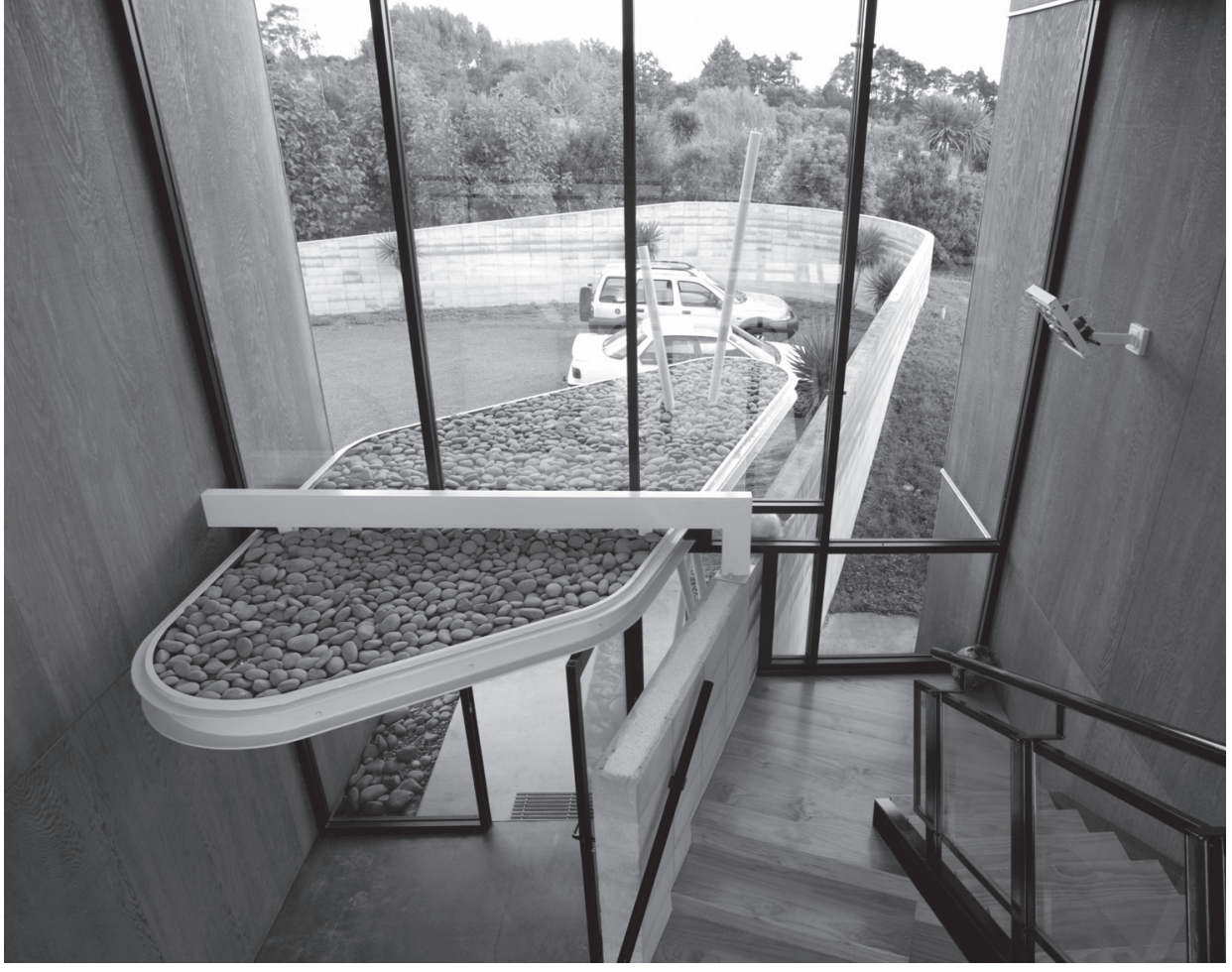

The notion of encampment suggests ways of playing with ideas of courtyard housing without providing courtyards. Comfort with openness is contrasted with dis-comfort with closure, when large buildings are split into a number of smaller forms, gathered about the site in ways that imply multiple relationships (building to building, building to landscape). New spaces are generated within the cluster, and between the buildings, as the delicate balance between too much attachment, too much closure, too much solidity is explored. For me, the intention is only to suggest desired spaces and relationships: to make abstract connections rather than literal ones. There should be room for misinterpretation.
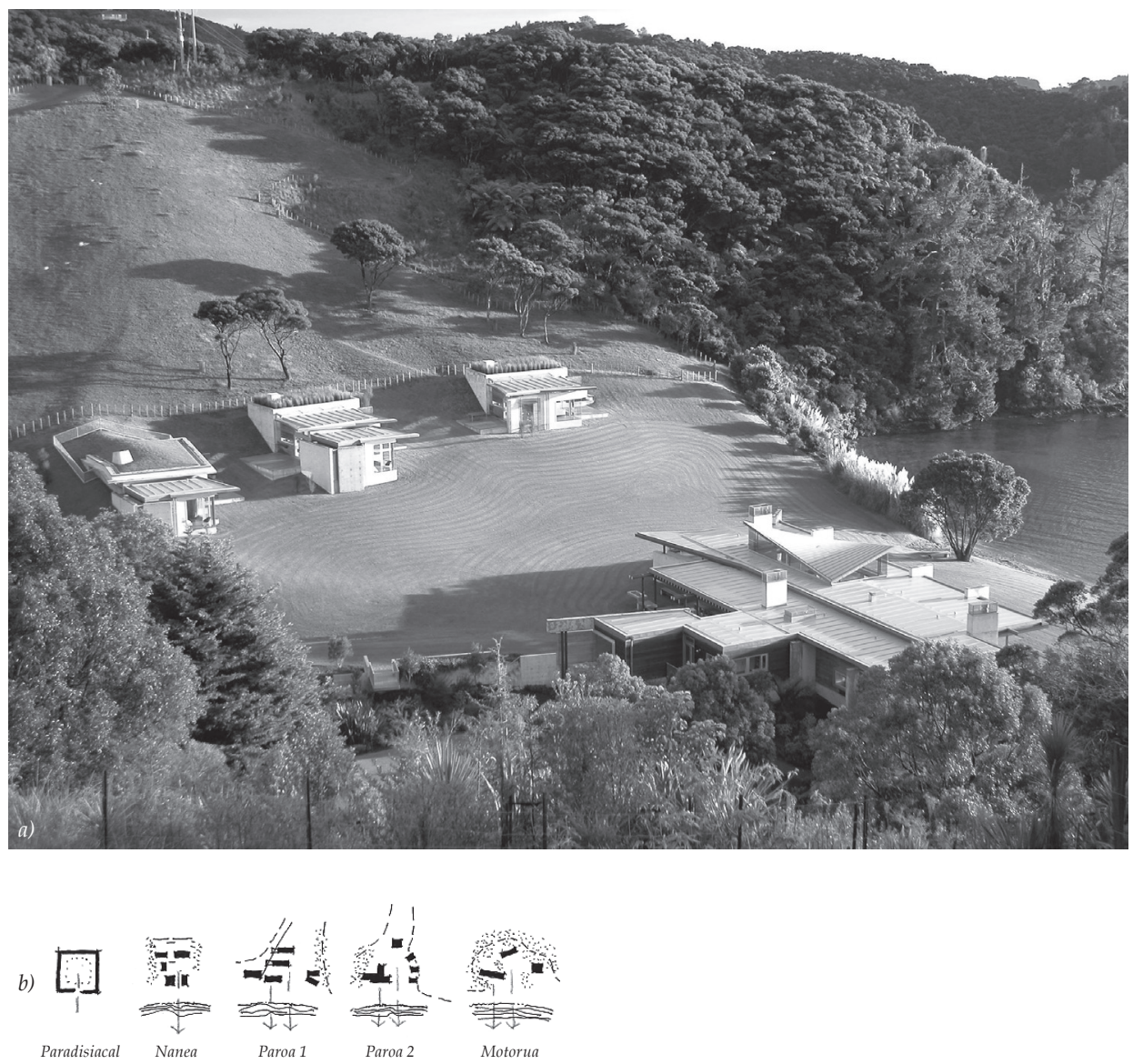


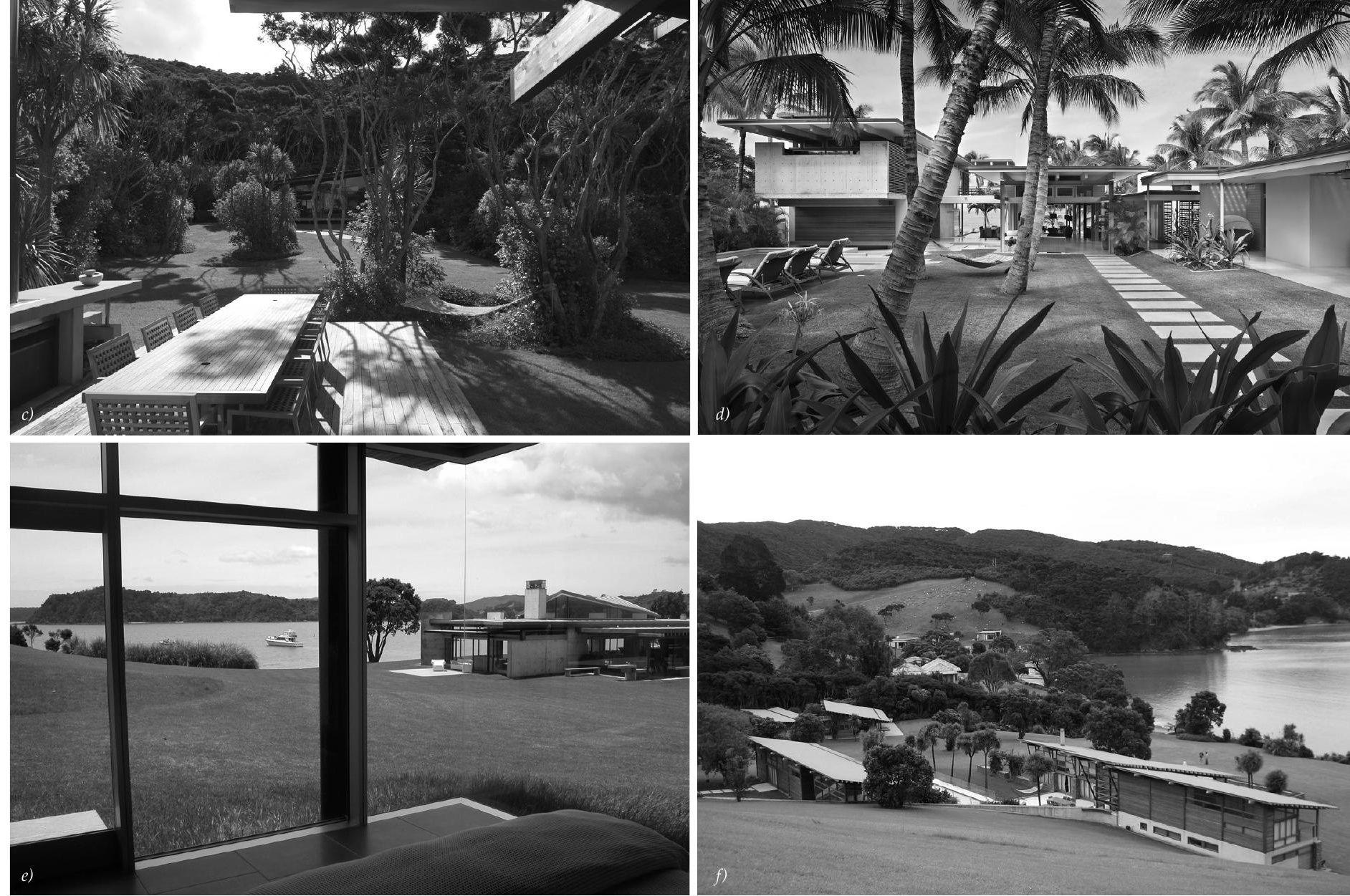

These holiday houses recall camping grounds, caravans and tents, and childhood holidays by sea or river, often in untended paddocks with overgrown grass. Teeming with pleasurable nostalgia, these memories and references thread into the architecture, which leaves the links between buildings uncharted and unprotected. When crossing between buildings, one feels the damp grass under one's bare feet, the chilly air on one's skin. The sense of being on holiday contrasts with the urban condition, which nevertheless continues to be present in its absence.

Such ideas have underpinned our designs for many years. There are others, like the pavilion, or the fluidity and sensuality of space, which always offers the power to enthral, or the opportunities offered by concepts relating to formlessness. Surface and decoration frequently exercise our wits. The delicate balance between suggestion and overstatement, between a light touch and a weighty one, provides an endless field of study. New Zealand conditions of openness, and its ever-shifting zones of slippage and disturbance, offer ideal grounds for such explorations. This place is fascinating and open and fertile. Fortunately, it is not Paradise. c) Motorua (Bay of Islands, 1999). Pavilions in recreated nature. Buildings, vegetation and contours suggest enclosure without formally creating it. Photo: Patrick Reynolds.

d) Nanea (Hawaii, 2009). The semienclosed area 'leaks' space at the corners and through the buildings themselves. Photo: Simon Devitt.

e) Paroa 2 House. The relationship between discrete buildings draws the exterior space into the composition, with the exterior terrace becoming the summer 'heart' of the encampment. Photo: Pete Bossley Architects.

f) Paroa 1 House (Bay of Islands, 2001). Pavilions arrayed with varying formality to provide a variety of exterior enclosures. Photo: Pete Bossley Architects. 